
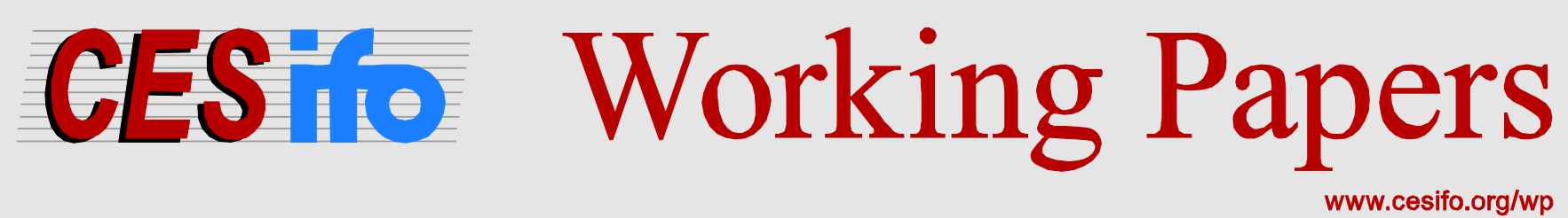

\title{
The Effect of Temporary Migration Experience on Occupational Mobility in Estonia
}

\author{
Jaan Masso \\ Raul Eamets \\ Pille Mõtsmees
}

CESIFO WORKING PAPER NO. 4322

CATEGORY 4: LABOUR MARKETS

JULY 2013

An electronic version of the paper may be downloaded

- from the SSRN website:

- from the RePEc website:

- from the CESifo website:

WWW.SSRN.com

www.RePEc.org

www.CESifo-group.org/wp

\section{CESifo}




\title{
The Effect of Temporary Migration Experience on Occupational Mobility in Estonia
}

\begin{abstract}
The literature on return migration includes several studies on the impact of foreign work experience on the returnees' earnings or their decision to become self-employed; however in this paper we analyze the less studied effect on occupational mobility, i.e. how the job in home country after return compares to the one before migration. The effect of temporary migration on occupational mobility is analyzed using a unique data from Estonian online job search portal covering ca $10-15 \%$ of total workforce that includes thousands of employees with temporary migration experience. The focus on a data from a Central and Eastern European country is motivated by that the opening of the old EU countries' labour markets for the workforce of the new member states has led to massive East-West migration. We did not find any positive effect of temporary migration on upward occupational mobility and in case of some groups, like females, the effect was negative. The results could be related to the typically short term nature of migration and the occupational downshifting abroad as well as the functioning of home country labour market.
\end{abstract}

JEL-Code: F220, J620.

Keywords: occupational mobility, temporary migration, Central- and Eastern Europe.

Jaan Masso
University of Tartu
Faculty of Economics and Business
Administration
Narva mnt. 4
Estonia - Tartu, 51009
Jaan.Masso@mtk.ut.ee

Jaan Masso

of Economics and Business

Administration

Estonia - Tartu, 51009

\author{
Raul Eamets \\ University of Tartu \\ Faculty of Economics and Business \\ Administration \\ Narva mnt. 4 \\ Estonia - Tartu, 51009 \\ raul.eamets@mtk.ut.ee
}

\author{
Pille Mõtsmees \\ University of Tartu \\ Faculty of Economics and Business Administration \\ Narva mnt. 4 \\ Estonia - Tartu, 51009 \\ pille.motsmees@ut.ee
}

\begin{abstract}
We are grateful to CV-Keskus for granting access to the data used in the paper. We thank Kärt Rõigas for excellent research assistance. We also thank Mihkel Reispass from Statistics Estonia for coding the occupations' data. Financial support from the Government Office of Republic of Estonia project no 1.5.0109.10-006 “Occupational mobility in Estonia - involved factors and effects”, the Estonian Science Foundation grant no. 8311 and Ministry of Education and Research of the Republic of Estonia target financed project no. SF0180037s08 are gratefully acknowledged. Authors are also grateful to CESifo Institute for excellent research facilities and Social Policy and Labour Markets department seminar participants for useful comments. The authors take the sole responsibility for all errors and omissions.
\end{abstract}




\section{Introduction}

The opening of the old EU countries' labour markets for the workforce of the new member states has lead to massive East-West migration. That is especially the case of Baltic States, incl. Estonia (Hazans, Philips 2011). While outward migration, especially of the young and educated people, may seriously undermine the further competitiveness of the countries, temporary or return migration may be also for the benefit of the countries, if the migrants attain new skills to be used later at sending country or if they accumulate savings in order to start with entrepreneurship ${ }^{2}$. There are three major channels through which international labor migration is considered to have a direct positive effect on development of the sending country: return migration, remittances, and the transfer of knowledge, technology or investments (Lowell and Findlay, 2002; Katseli et al. 2006) ${ }^{3}$.

In this paper we study the relationship between temporary migration and the occupational mobility of the employees, i.e. whether the human capital acquired abroad enables to take more highly paid jobs or jobs requiring higher human capital. The existing literature on return migrants has analyzed a lot the impact of foreign work experience on the earnings of the returning migrants or their decision to become self-employed. Socio-economic motivations and determinants of return migration have been extensively analysed in the literature (e.g. Borjas and Bratsberg, 1996; Dustmann 2003; Cobo et al 2010), most studies focused mainly on the decision of migrants to return to their home country and the amount of time spent abroad. Wage premiums of temporary migrants are also under observation (Iara 2006; Barrett and O’Connell 2001; Co et al. 2000; de Coulon and Piracha 2005; Hazans 2008; Brownell 2010; Dustmann 2003; Luthra 2009) with studies mostly confirming the higher earnings of

\footnotetext{
${ }^{2}$ We use temporary and return migration as synonyms. According to EU definitions temporary migration is migration for a specific motivation and/or purpose with the intention that, afterwards, there will be a return to country of origin or onward movement (European Migration Network, 2011). In this sense return migration is broader concept as it consists also those returners, who left country long time ago. Temporary migration is more short-term phenomenon. From economic point of view we do not see big differences between two categories.

${ }^{3}$ Its commonly claimed that migrants return with newly acquired specific experience, skills and savings that are likely to raise domestic productivity and employment upon repatriation (Lowell and Findlay, 2002; Fan and Stark, 2007). Savings of returning migrants may be used to acquire durable consumption goods, and to allow for a steady income after returning, but savings may also be put into productive use. Savings and remittances of migrants may provide badly needed capital inflows. For instance Kahanec and Shields (2010) found that temporary migrants work more hours in order to accumulate savings and invest in financial capital that can be transferred back to their country of origin upon return.
} 
return migrants. Gibson and McKenzie (2011) find the main forms of knowledge flow of high-skilled migrants from Ghana, Micronesia, Papua New Guinea, and Tonga are information about educational and work opportunities abroad, with few migrants providing advice to home country companies or governments. On the other hand there are also doubts about the positive effects on human capital of return migrants, e.g. due to outward migration reacting to the shortage of unskilled labour in destination countries (Mesnard 2004) or the applicability of the specific skills acquired in foreign country may be limited due to technological gap between receiving and sending country (Katseli et al. 2006).

The literature on return migration is not very big and there are only a few papers dealing with occupational change or mobility of the return migrants. Naturally, the effects of wages and occupation could be related as occupational change may be one channel via which the migration affects the earnings of the return migrants. Occupational mobility or choice can be understood in this context as the upward or downward mobility based on ranking of occupations at various level of detail (e.g. 1-digit ISCO classification) based on the earnings offered or human capital required at various occupations (e.g. Campos and Dabušinskas 2009, Carletto and Kilic 2011). Given the few earlier studies, Cobo et al. (2010) by using a multinomial logit model looked at the occupational choice of Latin-American return migrants to US by distinguishing between 5 categories of occupations; these were non-manual high qualification, non-manual low qualification, manual high qualification, manual low qualification, unemployed. They found that return migration enhanced upward occupational mobility especially at young age. Carletto and Kilic (2011) analyzed the occupational mobility of Albanian return migrants across 6 categories (not working, agriculture, lowskilled blue-collar, high-skilled blue collar, low-skilled white collar, high-skilled white collar), they found that upward occupational mobility was enhanced by past migration to Italy or countries further afield but not to Greece. Kupets (2011) using Ukrainian data found that return migration did not bring expected brain gain for economy. Majority of Ukrainian temporary migrants engaged in non-farm activities end up in working in informal sector, predominantly in construction, trade and repair. Ilahi (2009) modelled occupational choice of return migrants between wage employment, self-employment in agricultural activities, selfemployment in non-agricultural activities; he found that return migrants have higher tendency for self-employment over wage employment. 
The aim of our paper is to investigate occupational mobility of temporary migrants in Estonia, a new member state of the European Union since 2004. The eastern enlargement of the EU and lifting of the restrictions of the free movement of labour ${ }^{4}$ has led to massive east-west migration and Baltic States, especially Latvia and Lithuania but also Estonia, have demonstrated the highest labour outflow rates among the new member states after EU enlargement (Hazans 2008). The majority of migrants from new member states have been temporary (Hazans, Philips 2011), thus it's the very acute research question what is the impact of the return migration, e.g. whether the loss of human capital due to the emigration of the youngest and most capable employees is at least partly compensated by the returnees' accumulated higher human capital during the time of working abroad. For instance, Hazans (2008) found in Latvian case by using instrumental variables and propensity score matching techniques that returnees acquired substantial (one the average 15\%) wage premium.

For our study we would use unique dataset of the leading online job search portal (hereinafter CV-Keskus) for Estonia data that contains about 261 thousand self-reported resumes of jobsearchers. Due to its size the data includes thousands of employees with foreign work experience making it more appropriate for the analysis as compared to the labour force survey data. Many earlier studies of return migrants have been based on quite small samples of returnees, even less than one hundred returnees (Hazans 2008). Our advantage is that we have also some information on the jobs held abroad (duration, host country, occupation), e.g. differences in the duration of foreign experience may affect the returns to migration (Commander et al. 2013).

To sum, our contribution to the literature is that we extend the so far limited list of studies on the connections between return migration and occupational mobility by using a more detailed occupational ranking (based on 1-digit ISCO classification) and a much larger sample of returnees as used previously. That enables us to study whether the effects of return migration on labour market performance after return differ across the destination countries, duration of temporary migration or the kind of job held abroad. In addition to that it is also relevant that we contribute to the so far limited literature on the post-enlargement return migrants of the new EU member states.

\footnotetext{
${ }^{4}$ Different countries lifted the restrictions on free movement of labour at different times, incl. Ireland UK and Sweden at $1^{\text {st }}$ of May 2004, Finland, Greece, Italy, Spain and Portugal at $1^{\text {st }}$ of May 2006, Netherlands at $1^{\text {st }}$ of May 2007 (Randveer, Rõõm 2009).
} 


\section{Overview of the online job search portal data used in the analysis}

In our study we use the dataset from the largest on-line job search portal of Estonia, CVKeskus. The extract from the database made in January 2010 includes about 261 thousand resumes from job seekers. The resumes were mostly updated during 2008-2009 (i.e. the period covered in our data ends with early 2009). Depending on the year, the data covers about $10-15 \%$ of employment in Estonia (50-90 thousand employees) for 2000-2009. The data on employment history includes their last five jobs that are used to calculate various occupational mobility and migration indicators. For each of the 5 jobs, we know name of employer, country of employer, job start and end dates with monthly precision, and job title and category ${ }^{5}$. The information on employers (like industry of employment) was obtained by matching the CV Keskus data with Estonian Business Registry data based on employer's names. In addition, the data includes general background information (age, family status), information about education, training courses, skills (e.g. languages) and also a description of the person's desired job and wage. That kind of data is little used in economic research and has clear advantages in terms of sample size and informational content. Yet we also acknowledge the weaknesses of the data, as these work histories are self-reported and we do not know what kind of information was left out as undesired by applicant. Many data fields (like occupation, education) do not follow standard classifications and are filled with open text by the owner of CV.

According to our data, the percentage of people working abroad was in $20032.8 \%$, but increased to 5.3\% in 2007 and decreased to 5.1\% in 2009. These numbers probably do not include most of the permanent migrants not considering returning to Estonia, i.e. we observe mostly temporary flows ${ }^{6}$. Given that we have available up to 5 last jobs for each individual together with the countries of employment, we are also able to identify the return migrants. The definitions are based on the location, entry and exit dates of jobs, i.e. returnees are the ones having after the job abroad the next job in Estonia. In our analysis we will focus only on those migrants that had a job before outward migration, yet it has been shown that among migrants as compared to stayers there is a higher proportion of unemployed or students indicating that work abroad has been a coping strategy (Hazans, Philips 2011). In total, in our

\footnotetext{
${ }^{5}$ There were 24 categories, including e.g. "Sales”, “Construction / Real Estate”, “Tourism / Hotels”. These categories did not follow the standard ISCO occupational classifications and thus we did not use these.

${ }^{6}$ The estimated migration flows from new to old member states tend to be much lower when reported by the sending countries and higher as reported by the receiving countries (Randveer, Rõõm 2009).
} 
data we identified 7,557 temporary migrants. For comparison, many earlier studies have had only a rather small number of return migrants (Hazans 2008), e.g. Iara (2006) 93 or Barrett and O’Connell (2001) 158, while Hazans (2008) had about 500 of return migrants.

The most significant destination countries are Finland (41\% in 2008), UK (12.3\%), Norway (9.2\%), Ireland (7.1\%), US (4.6\%). The rather short distance between Estonia and Finland and good ferry connections makes commuting possible (returning to home for weekends). The average length of working spell is at home country (Estonia) about 28 months and in abroad about 15 months. The shorter job tenure among migrants also indicates the temporary nature of migration. The variation across countries is not very large, for the most frequent destination countries (Finland, UK, Ireland, US) it is in the range of 10-17 months.

The peculiarity of Estonian outward migration is that the largest numbers of Estonian emigrants have moved to the neighbouring country Finland. The potential criticism to interpreting the working of Estonians in Finland as international migration is that it should be considered rather as commuting due to the closeness of the two countries (the distance between the capitals Tallinn and Helsinki being just 85 kilometers), similar cultures and language (high percentage of Finnish speakers especially among the Northern-Estonian population). We may argue that even in these conditions it need not to be equivalent to the commuting within Estonia as still there are differences between Estonia and Finland (language, costs of migration), still it is expected that there are weaker selection of migration to Finland. For instance, Estonian migrants to Finland are relatively older compared to migrants in other countries being much younger (Hazans and Philips 2011). As the solution, we have undertaken several of the calculations also separately for migrants to Finland versus the migrants to other foreign countries ${ }^{7}$.

Table 1 outlines the majour differences between the personal characteristics of the various labour market participants, these are 1) stayers (without foreign work experience), 2) potential migrants (without foreign experience, but willing to do that), 3) stayers not willing to work abroad, 4) return migrants, 5) not-return migrants (still working abroad). Many of the differences are similar to expectations and earlier studies - among migrants there is higher

\footnotetext{
${ }^{7}$ King and Skeldon (2010) provide the discussions of the relationship between internal and international migration arguing that while the distinction between international and internal migration is becoming blurred the studies of these two have still been apart from each other and there is little studies comparing the effects of internal and international migration.
} 
frequency of those without children, males, youngsters; the same differences also show up when comparing returnees and not returned migrants. Non-Estonians are more ready to work abroad and possibly also stay there for longer periods (if not permanently) shown by their lower percentage among the returnees. The observed differences in education and skills are in accordance with Hazans and Philips (2011) - those with lower skill or education level are more ready migrate, return migrants show the highest level of education and not return migrants are between the two groups. Hazans (2008) found similarly that disproportionately many return migrants had high levels of human capital.

Table 1 The main socio-economic characteristics of stayers and migrants

\begin{tabular}{|c|c|c|c|c|c|c|}
\hline Variable & Stayer & $\begin{array}{c}\text { Stayers not } \\
\text { ready to } \\
\text { work } \\
\text { abroad } \\
\end{array}$ & $\begin{array}{c}\text { Stayers } \\
\text { ready to } \\
\text { work } \\
\text { abroad }\end{array}$ & $\begin{array}{l}\text { Return } \\
\text { migrants }\end{array}$ & $\begin{array}{c}\text { Not } \\
\text { returned } \\
\text { migrants }\end{array}$ & All \\
\hline Age up to 24 & $29 \%$ & $29 \%$ & $29 \%$ & $24 \%$ & $28 \%$ & $29 \%$ \\
\hline Age 25-49 & $61 \%$ & $62 \%$ & $63 \%$ & $72 \%$ & $67 \%$ & $62 \%$ \\
\hline Age 50-75 & $8 \%$ & $8 \%$ & $7 \%$ & $4 \%$ & $5 \%$ & $8 \%$ \\
\hline Female & $57 \%$ & $59 \%$ & $36 \%$ & $46 \%$ & $41 \%$ & $56 \%$ \\
\hline Kids (dummy) & $39 \%$ & $39 \%$ & $36 \%$ & $33 \%$ & $33 \%$ & $38 \%$ \\
\hline Cohabitation (dummy) & $49 \%$ & $50 \%$ & $46 \%$ & $46 \%$ & $44 \%$ & $49 \%$ \\
\hline Tertiary education & $17 \%$ & $17 \%$ & $12 \%$ & $19 \%$ & $15 \%$ & $17 \%$ \\
\hline Secondary education & $55 \%$ & $56 \%$ & $51 \%$ & $57 \%$ & $55 \%$ & $55 \%$ \\
\hline Primary education & $28 \%$ & $27 \%$ & $37 \%$ & $24 \%$ & $30 \%$ & $28 \%$ \\
\hline Mother tongue Estonian & $61 \%$ & $62 \%$ & $54 \%$ & $71 \%$ & $67 \%$ & $61 \%$ \\
\hline Mother tongue Russian & $32 \%$ & $31 \%$ & $36 \%$ & $27 \%$ & $28 \%$ & $32 \%$ \\
\hline Desired wage, EUR & 665.7 & 646.2 & 875.5 & 803.8 & 803.4 & 674.7 \\
\hline $\begin{array}{l}\text { Willingness to work } \\
\text { abroad, dummy }\end{array}$ & $9 \%$ & $0 \%$ & $100 \%$ & $25 \%$ & $36 \%$ & $11 \%$ \\
\hline
\end{tabular}

Note: The information on readiness to work abroad includes just one variable (yes/no).

It has been the peculiarity of Estonia that that people with low levels of education were more likely to migrate as in conditions of movement within EU there are no differences among entry barriers for low versus high skilled people (Randveer and Rõõm 2009). Another explanation could be that as highly-skilled individuals were also taking up low-skilled jobs abroad, they had lower returns to migration, thus previous occupation in Estonia could be related to the returns to migration.

Concerning work related migration intentions, about $11 \%$ of job-seekers are ready to work abroad. The percentage is about 3 times higher for those with some work experience in abroad (29\%), i.e. expectedly, those who have worked abroad are ready to do that again. The past work-experience matters for all groups of employees, but especially for blue-collars (10.9\% versus $31.8 \%)$ than white-collars (6.2\% vs. $18.6 \%)$, i.e. the group that is likely to have higher 
levels of factors inhibiting migration intensions (i.e. language). Foreign work experience is associated with higher desired wages ${ }^{8}$ in case of all categories of workers (on the average by $20 \%$ ), but even more in case of blue-collars (27\%), although the difference clearly exists also in case of white-collars ${ }^{9}$. There exist rather notable differences in desired wages for males and females. That reflects the Estonia's rather high gender pay gap of almost 30\%, yet it shows that the foreign experience matters also a bit more in case of males (14\% versus $19 \%$ differences in desired wages of returnees and stayers).

For the topic of our study, they key variable is the occupational categories of the jobs. The original data included only the names of the occupations, for instance, "secretary”, “doctor”, “dentist” et cetera. These were converted into the ISCO 88 4-digit codes by the specialists from the Statistics Estonia. To give readers some idea of the occupations, concerning occupations at the 4-digit levels, 2221 denotes “Doctors”, 222 "Health professionals (except nursing)", 22 "Life science and health professional” and 2 "Professionals". In the coding exercise in addition to the name of the occupation also the education of the employee (e.g. for teachers the presence of higher education is relevant for the occupational code) and the sector of the person's employer were considered. In a number of cases (e.g. occupation "operator”) the occupational code was left missing due to the absence of sufficient information. Table 2 presents the numbers on the structure of occupation on jobs in Estonia, as well as the numbers of the Statistics Estonia for comparison.

Table 2 Structure of occupations in the CV Keskus data and LFS data over time

\begin{tabular}{lcccccc}
\hline Occupational group & $\begin{array}{c}\text { CV } \\
\text { Keskus, } \\
\mathbf{2 0 0 3 ,} \\
\text { Estonia }\end{array}$ & $\begin{array}{c}\text { CV Keskus, } \\
\text { 2003, abroad }\end{array}$ & $\begin{array}{c}\text { CV } \\
\text { Keskus, } \\
\mathbf{2 0 0 9}, \\
\text { Estonia }\end{array}$ & $\begin{array}{c}\text { CV } \\
\text { Keskus, } \\
\mathbf{2 0 0 9 ,} \\
\text { abroad }\end{array}$ & $\begin{array}{c}\text { Statistics } \\
\text { Estonia, } \\
\text { LFS, 2003 }\end{array}$ & $\begin{array}{c}\text { Statistics } \\
\text { Estonia, } \\
\text { LFS, 2009 }\end{array}$ \\
\hline $\begin{array}{l}\text { Legislators, senior officials } \\
\text { and managers }\end{array}$ & 12.3 & 13.1 & 10.8 & 7.7 & 11.7 & 12.1 \\
\hline Professionals & 5.5 & 3.9 & 5.3 & 1.4 & 13.9 & 16 \\
\hline $\begin{array}{l}\text { Technicians and associate } \\
\text { professionals }\end{array}$ & 18.5 & 12.6 & 18.9 & 7.1 & 12.1 & 13.9 \\
\hline Clerks & 10.1 & 8.6 & 10.7 & 3.8 & 5.1 & 5.5 \\
\hline $\begin{array}{l}\text { Service workers and shop } \\
\text { and market sales workers }\end{array}$ & 21.5 & 21.0 & 22.8 & 16.1 & 12.8 & 12.6 \\
\hline Skilled agricultural and & 0.3 & 1.3 & 0.2 & 0.6 & 2.5 & 1.5 \\
\hline
\end{tabular}

\footnotetext{
${ }^{8}$ We have decided to not call the indicated wage as reference wage but rather as the desired wage. While that number could be quite different from the actual wages, perhaps surprisingly in a study by Mõtsmees and Meriküll (2012) on the gender pay gap the estimated gap using the wages reported in the CV Keskus data was very similar to the ones estimated from labour force survey data and actual wages.

${ }^{9}$ That is in line with the findings of Hazans (2008) that among the manual workers the return migrants enjoyed much higher earnings premium as compared to non-manual workers.
} 


\begin{tabular}{lcccccc}
\hline Occupational group & $\begin{array}{c}\text { CV } \\
\text { Keskus, } \\
\text { 2003, } \\
\text { Estonia }\end{array}$ & $\begin{array}{c}\text { CV Keskus, } \\
\text { 2003, abroad }\end{array}$ & $\begin{array}{c}\text { CV } \\
\text { Keskus, } \\
\mathbf{2 0 0 9 ,} \\
\text { Estonia }\end{array}$ & $\begin{array}{c}\text { CV } \\
\text { Keskus, } \\
\text { 2009, } \\
\text { abroad }\end{array}$ & $\begin{array}{c}\text { Statistics } \\
\text { Estonia, } \\
\text { LFS, 2003 }\end{array}$ & $\begin{array}{c}\text { Statistics } \\
\text { Estonia, } \\
\text { LFS, 2009 }\end{array}$ \\
\hline fishery workers & & & & & & \\
\hline $\begin{array}{l}\text { Craft and related trade } \\
\text { workers }\end{array}$ & 11.9 & 16.2 & 12.1 & 37.7 & 15.8 & 14.1 \\
\hline $\begin{array}{l}\text { Plant and machine operators } \\
\text { and assemblers }\end{array}$ & 6.0 & 4.3 & 5.2 & 4.5 & 14 & 14.3 \\
\hline Elementary occupations & 13.8 & 19.0 & 14.0 & 21.1 & 11.5 & 9.5 \\
\hline White-collars & 46.4 & 38.2 & 45.7 & 20.1 & 42.8 & 47.5 \\
Blue-collars & 53.6 & 61.8 & 54.3 & 79.9 & 56.6 & 52.0 \\
\hline N & & & & & &
\end{tabular}

Notes. LFS - labour force survey.

In our data the share of blue-collared occupations is somewhat higher as compared to the aggregate data because white-collars are expected to use to large variety of other channels of job search. The category 6 "Skilled agricultural and fishery workers" is underrepresented but that should not be a major problem given it is the smallest of the 1-digit occupational categories. The jobs held in abroad are quite different from the ones in Estonia: the share of white-collar jobs is drastically lower than in Estonia. That is in accordance with other studies showing that most of the migrants from CEE countries are employed in various manual or low-skilled jobs (Hazans 2008; Mattoo et al. 2008). It seems to be at least partly caused both by non-random selection, i.e. people at blue-collar jobs are more eager to migrate (e.g. due to the higher wage and unemployment gaps among people with lower level of education, Randveer and Rõõm 2009), but even people working in white collar jobs in Estonia are ready to work in blue-collar jobs in abroad due to the large income gaps between Estonia and sending countries ${ }^{10}$. Immigrants may work in the host country labour markets in jobs which they are over-qualified due to the less than full utilization of their skills, at least in the beginning (Dustmann et al. 2008). The migrants from NMS accepting these jobs may be also related to that their migration is temporary. In case of Baltic States it has been found that among the higher educated up to $70 \%$ migrants were over-qualified for their job (Hazans, Philips 2011).

\section{Occupational mobility: measurement issues and descriptive evidence}

Occupational mobility has been rather common phenomenon in the sample period: during 1993-2009, in each year 5-13 percent of people change their occupation, defined at the level 1-digit ISCO codes. In most cases employees switching occupations also change firm and

\footnotetext{
10 In the East-West migration in the extreme case the highest paid sector or occupation in the source country could be less rewarding than the highest paid one in the destination country (Commander et al. 2013).
} 
sector (i.e. these are complex switches as defined by Neal 1999): among all the occupational changes $11 \%$ occur within the firm, $13 \%$ include change of the employer within the same 2digit NACE Rev. 2 industries and 76\% involve both the change in the firm and industry; these proportions were similar among return migrants and stayers. One possible explanation could be peculiarity of our data: job-seekers may have limited incentives to report in the CV the different jobs within the same organization. For comparison, in Campos and Dabušinskas (2009) for 1989-1995 according Estonian LFS data the share of complex switches was 69\%. Only about $10-25 \%$ of the occupational flows are related to the changes in the overall structure of occupations (e.g. decreasing share of blue-collar jobs).

Next we consider the direction of the occupational mobility, i.e. the career mobility or occupational upgrading. The occupations could be ranked according to average earnings, the amount of human capital required or the prestige of the occupation (Sicherman and Galor 1990). Upward or downward occupational mobility is then the vertical movement in this ladder of occupations. In the previous studies, vertical occupational mobility has been measured differently, for instance Campos and Dabušinskas (2009) used 1-digit ISCO (9) categories and Sabirianova (2002) 2-digit categories (28) categories. Hereby following Sicherman and Galor (1990) and Campos and Dabušinskas (2009) we use the vertical ranking of the 1-digit ISCO 88 occupations based either on the returns to various occupations (how much these increase wages after controlling for other factors) or based on their average level of human capital required in the respective occupation. The earnings ladder was constructed similarly to Sabirianova (2002) by estimating the returns to occupations based on wage regressions using the different waves of the Estonian LFS data for years 1996-2009, where the log of the hourly net wage was regressed on employee's age and a set of occupational dummy variables $^{11}$. The educational rankings were based on the derived index of the amount of human capital needed for different occupations that was calculated similarly following Sabirianova (2002) and Campos and Dabušinskas (2009) based on estimated Mincerian wage regressions $^{12}$. Our estimated educational ranking is strikingly similar to the one derived by Campos and Dabušinskas (2009); they also found little variations in the schooling rankings

\footnotetext{
${ }^{11}$ As it was said, the CV Keskus data included the wage data only for a subset of observations and the reported wage indicator was the desired wage, not the actual wage.

${ }^{12}$ For instance, the ranking based on earnings in year 2006 is as follows - 1- legislators, senior officials and managers (1); 2 - professionals (ISCO code 2); 3 - technicians and associate professionals (3); 4 - armed forces (0); 5 - craft and related trade workers (7); 6 - clerks (4); 7 - plant and machine operators and assemblers (8); 8 skilled agricultural and fishery workers (6); 9 - service workers and shop and market sales workers (5); 10elementary occupations (9).
} 
for years 1989-1994. Also the educational and earnings-based rankings are quite highly correlated.

Table 3 The probability of upward occupational mobility by different workers' characteristics

\begin{tabular}{|c|c|c|c|c|c|c|c|c|}
\hline Value & $\begin{array}{l}\text { Has not } \\
\text { worked } \\
\text { abroad }\end{array}$ & $\begin{array}{c}\text { Has } \\
\text { worked } \\
\text { abroad }\end{array}$ & $\begin{array}{l}\text { Worked } \\
\text { abroad } \\
\text { in blue- } \\
\text { collar } \\
\text { position }\end{array}$ & $\begin{array}{l}\text { Worked } \\
\text { abroad } \\
\text { in white- } \\
\text { collar } \\
\text { position }\end{array}$ & $\begin{array}{c}\text { Worked } \\
\text { abroad } \\
\text { in } \\
\text { Finland }\end{array}$ & $\begin{array}{l}\text { Worked } \\
\text { abroad in } \\
\text { country } \\
\text { other than } \\
\text { Finland } \\
\end{array}$ & $\begin{array}{l}\text { Abroad } \\
\text { up to } 1 \\
\text { year }\end{array}$ & $\begin{array}{c}\text { Worked } \\
\text { abroad } \\
\text { more } \\
\text { than } 1 \\
\text { year } \\
\end{array}$ \\
\hline \multicolumn{9}{|c|}{ Educational ranking } \\
\hline Age up to 24 & $62.5 \%$ & $64.9 \%$ & $62.5 \%$ & $69.4 \%$ & $66.5 \%$ & $64.3 \%$ & $65.0 \%$ & $65.7 \%$ \\
\hline Age 25-49 & $60.0 \%$ & $53.2 \%$ & $51.1 \%$ & $57.7 \%$ & $48.5 \%$ & $54.9 \%$ & $54.5 \%$ & $50.6 \%$ \\
\hline Age $50-75$ & $44.1 \%$ & $39.1 \%$ & $36.8 \%$ & $45.8 \%$ & $37.9 \%$ & $39.7 \%$ & $39.5 \%$ & $34.9 \%$ \\
\hline Tertiary education & $59.1 \%$ & $54.5 \%$ & $53.4 \%$ & $56.2 \%$ & $46.5 \%$ & $55.8 \%$ & $59.4 \%$ & $45.1 \%$ \\
\hline $\begin{array}{l}\text { Secondary } \\
\text { education }\end{array}$ & $58.0 \%$ & $54.6 \%$ & $51.0 \%$ & $63.4 \%$ & $55.3 \%$ & $54.2 \%$ & $56.9 \%$ & $47.1 \%$ \\
\hline Primary education & $59.7 \%$ & $56.6 \%$ & $54.3 \%$ & $61.5 \%$ & $53.0 \%$ & $58.0 \%$ & $57.3 \%$ & $55.0 \%$ \\
\hline Females & $61.5 \%$ & $60.8 \%$ & $56.7 \%$ & $63.6 \%$ & $59.4 \%$ & $61.1 \%$ & $61.8 \%$ & $57.4 \%$ \\
\hline Males & $55.6 \%$ & $51.2 \%$ & $49.7 \%$ & $54.9 \%$ & $49.3 \%$ & $52.2 \%$ & $53.3 \%$ & $47.4 \%$ \\
\hline Totals & $59.2 \%$ & $55.8 \%$ & $51.9 \%$ & $60.7 \%$ & $52.9 \%$ & $56.9 \%$ & $57.8 \%$ & $51.1 \%$ \\
\hline \multicolumn{9}{|l|}{ Earnings ranking } \\
\hline Age up to 24 & $64.4 \%$ & $65.2 \%$ & $63.1 \%$ & $69.1 \%$ & $61.9 \%$ & $66.5 \%$ & $64.8 \%$ & $68.6 \%$ \\
\hline Age 25-49 & $60.9 \%$ & $57.1 \%$ & $56.9 \%$ & $57.6 \%$ & $57.6 \%$ & $56.9 \%$ & $56.9 \%$ & $57.5 \%$ \\
\hline Age $50-75$ & $42.1 \%$ & $43.5 \%$ & $44.1 \%$ & $41.7 \%$ & $41.4 \%$ & $44.4 \%$ & $42.1 \%$ & $41.9 \%$ \\
\hline Tertiary education & $60.6 \%$ & $57.2 \%$ & $58.0 \%$ & $55.8 \%$ & $51.2 \%$ & $58.2 \%$ & $61.8 \%$ & $48.7 \%$ \\
\hline $\begin{array}{l}\text { Secondary } \\
\text { education }\end{array}$ & $59.6 \%$ & $55.8 \%$ & $54.2 \%$ & $59.7 \%$ & $55.3 \%$ & $56.1 \%$ & $56.3 \%$ & $52.9 \%$ \\
\hline Primary education & $60.1 \%$ & $60.4 \%$ & $59.4 \%$ & $62.4 \%$ & $60.7 \%$ & $60.2 \%$ & $59.5 \%$ & $63.0 \%$ \\
\hline Females & $61.0 \%$ & $59.6 \%$ & $56.3 \%$ & $61.1 \%$ & $58.4 \%$ & $59.9 \%$ & $59.9 \%$ & $58.0 \%$ \\
\hline Males & $58.6 \%$ & $58.2 \%$ & $59.2 \%$ & $59.0 \%$ & $58.1 \%$ & $58.3 \%$ & $58.7 \%$ & $57.3 \%$ \\
\hline Totals & $60.1 \%$ & $58.9 \%$ & $58.3 \%$ & $60.4 \%$ & $58.2 \%$ & $59.1 \%$ & $59.4 \%$ & $57.6 \%$ \\
\hline
\end{tabular}

Note. The mobilities are measured over various time periods at 2002-2009. For return migrants, the mobilities are calculated between the job in Estonia before and the job in Estonia after return migration.

Table 3 shows the probability of upward occupational mobility by different job rankings, for various groups of individuals and by the kind of the return-migration experienced (host country, job held abroad, length of stay). The frequency of upward mobility was $55 \%$ of all changes, while Campos and Dabušinskas (2009) for earlier period in Estonia found the upward and downward flows to be of broadly equal frequency. The proportion need not be equal to $50 \%$ due to the changing structure of occupations and the different occupations of individuals entering and exiting of the labour market. In general the upward mobility is somewhat lower among return migrants (as compared to stayers), and it seems to hold across different socio-economic groups (gender, education), yet the characteristics of the working spell in abroad seem to be somewhat important. Quite robustly, the downward mobility of 
return migrants seems to be related to their working at lower ranked, specifically, blue-collar jobs; as we saw, that is a quite a common characteristic even among the skilled migrants from CEE countries. The probability of upward mobility decreases with age and especially in case of older employees, the relationship between temporary migration and lower upward mobility can be seen. In a way that can be thus interpreted as evidence of brain waste, yet the interpretation should be limited, e.g. there is possible higher performance within a given occupation.

The differences between Finnish and other host countries return migrants are generally small and not consistent always. The longer stay abroad is mostly (but only marginally in case of 1digit occupations ranked by earnings) associated with higher probability of upward mobility.

\section{Method for studying the determinants of occupational mobility and temporary migration}

In previous studies the occupational mobility has been modelled either in the framework of a bivariate probit model (whether the particular kind of mobility takes place or not, e.g. Campos and Dabušinskas 2009), ordered probit model whereby the degree of mobility in the occupational ranking is modelled (Carletto and Kilic 2011), multinomial logit model (e.g. for upward mobility, downward mobility and staying at the same occupation, Cobo et al. 2010). Our dependent variable was the dummy for the upward occupational mobility. Similarly, for migration the modelled variable was the indicator variable of temporary migration. The probit model for temporary migration can be derived from the latent variable model, i.e. for individual $i$ the latent variable $r e t_{-} m_{i}{ }_{i}{ }^{*}$ is determined by the following equation:

(1) ret_mig ${ }_{i}^{*}=\beta_{1} x_{1 i}+\varepsilon_{1 i}$,

where $x_{1 i}$ is the vector of variables determining temporary migration and $\beta_{1}$ is the associated coefficient vector. Then ret_mig ${ }_{i}$ is the observed indicator variable for temporary migration that equals 1 for returnees and 0 for stayers. Person undertakes temporary migration $\left(\right.$ ret_mig $\left.g_{i}=1\right)$ if ret_mig ${ }_{i}{ }^{*}>c$, where c is some constant threshold level summarizing e.g. the costs and benefits to temporary migration. Similarly for upward mobility the equation will be as follows:

( 2 ) $u p_{-} m o b_{i}^{*}=\beta_{2} x_{2 i}+\varepsilon_{2 i}$,

where $u p_{-} m o b_{i} *$ is the latent variable, $x_{1 i}$ is the vector of variables determining mobility and $\beta_{1}$ is the associated coefficient vector. The indicator variable $u p_{-} m o b_{i}$ is equal to 1 for 
$u p_{-} m o b_{i}{ }^{*}>d$, where $d$ captures e.g. the returns to and costs of mobility (like returns to current and alternative occupations).

In order to infer the unbiased estimate of the effect of return migration on occupational mobility one needs to account for the non-random selection into return migration ${ }^{13}$. If there are unobservable variables affecting both the past migration decision and the outcome variable (occupational mobility) then not-accounting for non-random selection results in biased estimate of the effect of temporary migration on occupational mobility. Thus we have adopted instrumental variables approach. The instruments should be uncorrelated with the outcome variable (occupational mobility) to be exogenous but should be correlated with the endogenous variable (return migration) to be relevant ${ }^{14}$.

In case of temporary migration measured as a dummy we have the problem that both the treatement variable and the outcome variable (occupational mobility) are dummies, thus e.g. probit with instrumental variables can not be used (Woolridge 2002). Thus we use instead the bivariate probit. The seemingly unrelated bivariate probit model, where a variable (dummy for foreign work experience) appears both at the right of one equation and the left hand side of the other equation, has the same log-likelihood as the one for the binary outcome- binary instrument case (Greene 2000). Thus the following equations will be estimated jointly as the bivariate probit models:

$$
\begin{aligned}
& \operatorname{Pr}[\text { ret_mig }=1]=\operatorname{Pr}\left[\text { ret_mig }{ }_{i}^{*}>0\right]=\operatorname{Pr}\left[\gamma \cdot z_{i}+\beta_{1} x_{i}+\varepsilon_{1 i}\right] \\
& \operatorname{Pr}\left[u p_{-} m o b_{i}=1\right]=\operatorname{Pr}\left[u p_{-} m o b_{i}^{*}>0\right]=\operatorname{Pr}\left[\alpha \cdot r e t \_m i g_{i}+\beta_{2} x_{i}+\varepsilon_{2 i}\right]
\end{aligned}
$$

where $z_{i}$ denotes the set of instrumental variables. Similarly to earlier studies, we have additionally used the linear instrumental variables estimator while we acknowledge the issues related to linear probability models.

As the instruments we have use the dummies for co-habitation and the number of children. The validity of these instruments assumes that these influence the migration decisions, but not occupational mobility. As these instruments are expected to be more strongly correlated with

\footnotetext{
${ }^{13}$ To be more specific, in the econometric estimation of the effects of return migration ideally one would need to address different issues, like selection into migration (working abroad), selection into return migration, selection into employment and the inclusion in surveys (Hazans 2008).

${ }^{14}$ Thus in a similar modelling problem (Carletto and Kilic 2011) run the 1st stage probit model on the independent variables of the occupational mobility equation and the instruments, and the predicted values of the endogenous variable were used in the mobility equation.
} 
return migration in case of females, we performed the estimations also separately for females and males. Another instrument we considered was the past migration experience that is expected to be quite important for current migration. For instance, in our data among those having worked before 2006 the frequency of return migration during 2006-2009 was 46\%, while among those without that experience just $2.7 \%$. At the same time, these measures had no correlation with upward mobility variables, i.e. implying that any benefits from return migration in terms of occupational mobility are probably acquired relatively soon after return.

We use the determinants (push and pull factors) of occupational mobility in line with those used by Sabirianova (2002) and Campos and Dabušinskas (2009). Occupational mobility is expected to decrease with returns to current occupation, increase with returns to alternative occupation (i.e. the ones where the individual is likely to move), increases with transferability of skills between occupations and decrease with costs of mobility (e.g. current employerspecific investment), occupation specific match (experience in the same occupation). Returns to current and alternative occupations were calculated similarly to Sabirianova (2002) by running the following wage regressions using the Estonian labour force survey data:

( 4 ) $\ln \left(W_{i}\right)=\beta_{0}+\beta_{1} A G E_{i}+\sum_{k} \alpha_{k} \cdot O C C_{i k}+\sum_{k} \gamma_{k} \cdot O C C_{i k} \cdot A G E_{i}+u_{i} \cdot$

where $\ln \left(W_{i}\right)$ is the net $\log$ wage at main job, $O C C_{i}$ is the vector of occupational dummy variables, $A G E_{i}$ is the age of the person. The returns to current occupations are then calculated as $R T C_{i}=\alpha_{k}+\gamma_{k} A G E_{i}$ and returns to alternative occupation as $R T A_{i}=\sum_{k}\left(\alpha_{k}+\gamma_{k} A G E_{i}\right) P_{k l}$ for $l \neq k$, where $P_{k l}$ stands for the probability of transition from job $k$ to job $l$.

Skills transferability (STI) index captures the lost returns to past occupational investments and is thus expected to have negative association with occupational mobility. It measures the match of the qualification (education) and the occupations; for the qualification $q$ its has been calculated by the formula

(5) $S T I_{q}=1-\frac{\sum_{j=1}^{J}\left(N_{q, j}-\frac{N_{q}}{J}\right)^{2}}{N_{q}^{2}}$,

where $J$ is the number of occupational categories (i.e. 9 in case of 1-digit occupations), $N_{q, j}$ is the number of individuals with qualification $\mathrm{j}$ and occupation q, and $N_{q}$ is the total number 
of individuals at occupation $q\left(N_{q}=\sum_{j} N_{q, j}\right)$. The index is 1 for qualifications uniformly distributed across occupations and less than 1 in other cases (Campos and Dabušinskas 2009). As the calculated STI was missing due to missing educational data for many individuals, similarly to Sabirianova (2002) in these cases we replaced the missing values with average value of the STI index and included a dummy variable for the observations with missing STI index.

The cost of occupational mobility is captured by various individual variables. Tenure at current job measures firm-specific investment and is thus expected to have negative effect on inter-firm occupational mobility (that accounts for most of the mobility as we saw) while it may enhance intra-firm mobility due to career development (Sicherman and Galor 1990). Concerning education, while people with more schooling (e.g. tertiary education) are expected to have more opportunities for upward mobility, higher education is expected to be more specific and have a higher occupation-specific component (Sabirianova 2002). The other control variables are gender, actual work experience, age, broad sectoral dummies (primary, secondary, tertiary sectors).

In the equation for temporary migration mostly similar control variables will be used. For instance, the returns to different occupation could be important also for the migration decision, e.g. differences between the relative income by occupational groups in Estonia and destination countries favour the emigration of certain categories like low-skilled blue-collar workers (Randveer and Rõõm 2009). The reason for including the dummy for majority population (Estonians) is that Estonia has a large minority (mostly Russian speaking) population that was not covered directly from the removing of the legal restrictions of working in the EU countries after EU enlargement in 2004 in countries like UK and Ireland (Hazans 2008). The variables for age and gender capture that men and young people are more likely to migrate. Sectoral dummies are also expected to be important given that individuals in certain private sector branches (like construction) have had much higher propensities of outward migration.

\section{Results of econometric estimations}

Table 4 presents the results of the bivariate probit models that models the presence of occupational mobility and return migration with accounting for the endogeneity of the latter. 
In case of females there can be found evidence on negative effects of return migration on occupational mobility; that can be seen for rankings of occupations based on both wages and human capital,. While our motivation for running the estimates separately by gender was driven by the consideration of suitability of instruments, the evidence on the negative effects on females might be related to the generally weaker position of females in the home country (i.e. Estonian) labour market, i.e. if after return to the national labour market it is difficult for them to attain the job of equal quality and stable employment relation could be especially valuable for females. Another explanation could be their higher risk aversion not allowing females to have longer job search period and wait for better job offers. But even for males, the lack of evidence of positive effect of return migration might be potentially a warning signal. While several studies we mentioned have found positive impacts of return migration on wages (e.g. Hazans 2008 for Latvia) or occupational mobility (Cobo et al. 2010, Carletto and Kilic 2011), in fact the lack of positive or even negative effect of return migration has also been detected, e.g. negative wage premium for Albanian returnees (de Coulon and Piracha 2005), lower odds of getting employment among Finnish returnees due to lost contact with Finnish labour market (Saarela and Finnas 2009) and lower productivity of return migrants in Chinese venture capital industry (Sun 2013). Yet this evidence might be seen as consistent with the tendency for movers to work in abroad in jobs not corresponding to their level of education, shown e.g. our evidence presented in section 2 or Hazans and Philips (2011) reported high rates of over-qualification for the educated highly movers (6\%), but also for return migrants (38\% vs. 28 among stayers). The issues could be then about the lack of accumulation of the skills in abroad or the problems in making these useful in the home country labour market. The results for the occupational rankings based on wages and human capital are rather similar, that is not surprising given their high correlation. 
Table 4 Bivariate probit models for the determinants of occupational mobility and return migration

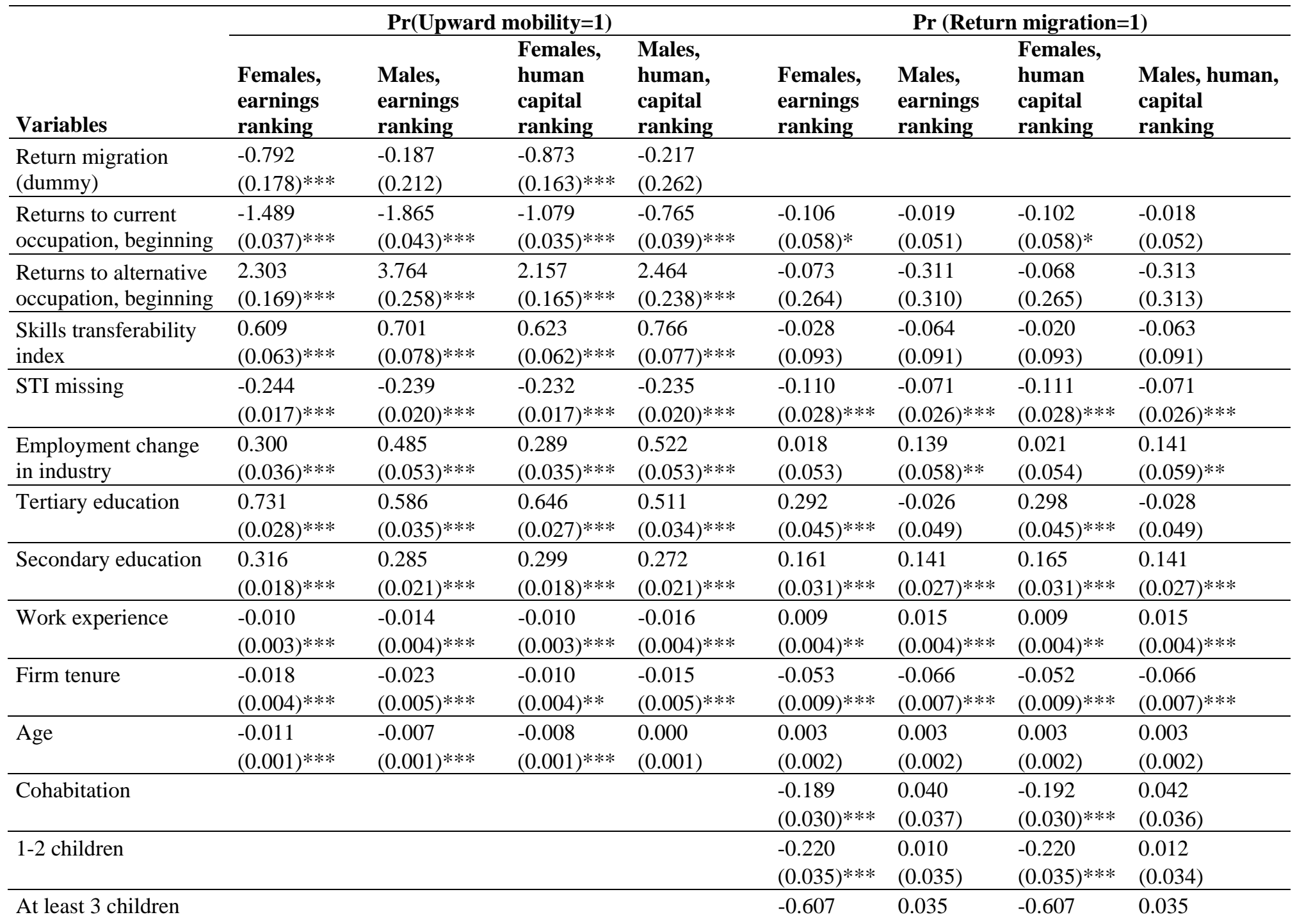




\begin{tabular}{|c|c|c|c|c|c|c|c|c|}
\hline \multirow[b]{2}{*}{ Variables } & \multicolumn{4}{|c|}{$\operatorname{Pr}($ Upward mobility=1) } & \multicolumn{4}{|c|}{ Pr (Return migration=1) } \\
\hline & $\begin{array}{l}\text { Females, } \\
\text { earnings } \\
\text { ranking }\end{array}$ & $\begin{array}{l}\text { Males, } \\
\text { earnings } \\
\text { ranking }\end{array}$ & $\begin{array}{l}\text { Females, } \\
\text { human } \\
\text { capital } \\
\text { ranking }\end{array}$ & $\begin{array}{l}\text { Males, } \\
\text { human, } \\
\text { capital } \\
\text { ranking }\end{array}$ & $\begin{array}{l}\text { Females, } \\
\text { earnings } \\
\text { ranking }\end{array}$ & $\begin{array}{l}\text { Males, } \\
\text { earnings } \\
\text { ranking }\end{array}$ & $\begin{array}{l}\text { Females, } \\
\text { human } \\
\text { capital } \\
\text { ranking }\end{array}$ & $\begin{array}{l}\text { Males, human, } \\
\text { capital } \\
\text { ranking }\end{array}$ \\
\hline & & & & & $(0.119)^{* * *}$ & $(0.072)$ & $(0.118)^{* * *}$ & $(0.072)$ \\
\hline $\begin{array}{l}\text { Worked abroad before } \\
\text { return migration }\end{array}$ & & & & & $\begin{array}{l}0.499 \\
(0.055) * * *\end{array}$ & $\begin{array}{l}0.567 \\
(0.049)^{* * *}\end{array}$ & $\begin{array}{l}0.496 \\
(0.054)^{* * *}\end{array}$ & $\begin{array}{l}0.566 \\
(0.049)^{* * *}\end{array}$ \\
\hline Estonian language & $\begin{array}{l}0.177 \\
(0.017) * * * \\
\end{array}$ & $\begin{array}{l}0.283 \\
(0.021)^{* * *}\end{array}$ & $\begin{array}{l}0.180 \\
(0.017)^{* * *}\end{array}$ & $\begin{array}{l}0.295 \\
(0.021)^{* * *}\end{array}$ & $\begin{array}{l}0.070 \\
(0.028)^{* *} \\
\end{array}$ & $\begin{array}{l}0.151 \\
(0.027)^{* * *}\end{array}$ & $\begin{array}{l}0.073 \\
(0.028)^{* * *}\end{array}$ & $\begin{array}{l}0.151 \\
(0.027)^{* * *}\end{array}$ \\
\hline Primary sector & $\begin{array}{l}0.147 \\
(0.066)^{* *}\end{array}$ & $\begin{array}{l}-0.021 \\
(0.066)\end{array}$ & $\begin{array}{l}0.209 \\
(0.065)^{* * *}\end{array}$ & $\begin{array}{l}-0.024 \\
(0.068)\end{array}$ & $\begin{array}{l}-0.006 \\
(0.109)\end{array}$ & $\begin{array}{l}0.037 \\
(0.089)\end{array}$ & $\begin{array}{l}-0.022 \\
(0.109)\end{array}$ & $\begin{array}{l}0.037 \\
(0.089)\end{array}$ \\
\hline Secondary sector & $\begin{array}{l}0.144 \\
(0.021)^{* * *}\end{array}$ & $\begin{array}{l}0.001 \\
(0.020)\end{array}$ & $\begin{array}{l}0.349 \\
(0.021)^{* * *}\end{array}$ & $\begin{array}{l}0.071 \\
(0.019)^{* * *}\end{array}$ & $\begin{array}{l}-0.099 \\
(0.037)^{* * *}\end{array}$ & $\begin{array}{l}0.059 \\
(0.026)^{* *}\end{array}$ & $\begin{array}{l}-0.093 \\
(0.037)^{* *}\end{array}$ & $\begin{array}{l}0.060 \\
(0.025)^{* *}\end{array}$ \\
\hline Number of obs. & 31953 & 24632 & 31953 & 24632 & 31953 & 24632 & 31953 & 24632 \\
\hline Log-likelihood & -22602.467 & -17810.749 & -23060.396 & -18119.683 & -22602.467 & -17810.749 & -23060.396 & -18119.683 \\
\hline
\end{tabular}

Notes: * significant at 10\%; ** significant at 5\%; *** significant at $1 \%$. In order to save space we have not reported the..... 
Concerning other explanatory variables, the sign of the variable of returns to current occupation has as the expected negative sign for upward mobility: a decrease in returns to current occupation is associated with an increase in occupational mobility. The returns to alternative occupation (measuring the outside options available to worker) on the other has a positive sign. For comparison, in the earlier study on Estonia Campos and Dabušinskas (2009) found these to have the statistically significant and expected signs only in 1994, not in the early transition (possibly switching occupations was not covered by the logic of the market economy in this time). While skills' transferability index did not perform well in earlier study on Estonia by Campos and Dabušinskas (2009) here it is strongly statistically significant and has the expected positive association with mobility. Skills transferability index and returns to current and alternative occupations are mostly not significant determinants of temporary migration. Both occupational mobility and temporary migration decrease with firm tenure (the loss of accumulated firm-specific human capital may reduce any kind of mobility), yet the overall labour market experience has negative effect on upward occupational mobility but the negative one temporary migration.

For the instruments of return migration the signs are mostly as expected - cohabitation and the presence of children reduce return migration in case of females but not males (i.e. the latter are not strong instruments for them). Earlier migration is strongly significant determinant of return migration of both males and females indicating the importance of experience and overcoming the psychological or other kinds of barriers or the importance of network effects. There are differences in the propensity of emigration by sectors (found also e.g. by Randveer and Rõõm 2009 higher rates in private sector compared to public sector). Those with mother language being Estonian are significantly more likely to be return migrants, either due to their higher propensity to migrate, but more probably the higher probability of Estonians to return. For instance, the survey among the firms showed that among the employed immigrants 32\% were in fact Estonians returning to their home country (Randveer and Rõõm 2009). Estonians demonstrate also higher upward mobility. Concerning education, secondary education is associated with migration among both sexes but tertiary education only among the females. Thus the lower-than-average educational attainment of migrants (Hazans and Philips 2011) seems to be driven more by the lower-educated males, while the emigration of higher educated females might bear some relation with the relatively lower wages in female-dominated occupations (Anspal et al. 2010) or their jobs in home country not corresponding to their level of education, however Hazans and Philips (2011) argued that the observed higher percentage (60\% in Estonia) of over-qualified of the highly educated movers was quite likely caused by moving and there is no evidence of over-qualification before moving. People 
with higher education are also more mobile, especially in terms of upward job mobility. The insignificant effect of age on migration may be related to its close correlation with tenure (in Hazans and Philips 2011 returnees were not very different from all migrants). The net employment change in the industry of the initial employer shows positive correlation with the both variables (different from Sabirianova 2002), e.g. in conditions of positive employment change there are more possibilities of upward mobility due to new jobs.

Table 5 The results of additional estimations on the effect of return migration on_occupational mobility

\begin{tabular}{|c|c|c|c|c|c|c|}
\hline \multirow[b]{2}{*}{ Return migration variable } & \multicolumn{3}{|c|}{ Wage ranking } & \multicolumn{3}{|c|}{ Human capital ranking } \\
\hline & All & Females & Males & All & Females & Males \\
\hline \multicolumn{7}{|l|}{ Bivariate probit model } \\
\hline Return migration & $-* \star \star$ & $-\star \star \star *$ & & $-* * *$ & $-\star \star \star *$ & \\
\hline Age up to 24 & $-* \star \star$ & $-\star \star \star \star$ & & $-* * *$ & $-\star \star \star \star$ & \\
\hline Age 25-49 & $-\star \star \star \star$ & $-\star \star \star \star$ & $-*$ & 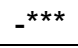 & 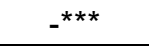 & $-*$ \\
\hline Age 50-75 & $-\star \star \star$ & & $-\star \star$ & $-* * *$ & $-\star \star \star *$ & $-\star \star \star *$ \\
\hline Return migration to Finland & $+* \star$ & $-*$ & $+* \star \star$ & & $-*$ & $+* \star$ \\
\hline $\begin{array}{l}\text { Return migration to countries } \\
\text { other than Finland }\end{array}$ & 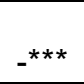 & $-\star \star \star *$ & $-* * *$ & $-* * *$ & $-\star * \star$ & $-\star \star \star *$ \\
\hline \multicolumn{7}{|l|}{$\begin{array}{l}\text { Return migration of at least } 1 \\
\text { year }\end{array}$} \\
\hline White collar job abroad & $-* \star \star$ & $-\star \star *$ & $-\star \star *$ & $-* * *$ & $-* \star \star$ & 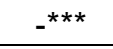 \\
\hline \multicolumn{7}{|l|}{ Linear probability models } \\
\hline Return migration & $-\star \star \star \star$ & $-\star \star \star \star$ & & $-* \star \star$ & $-\star \star \star \star$ & \\
\hline Age up to 24 & $-*$ & & & & & \\
\hline Age 25-49 & $-\star \star \star \star$ & & & $-* \star \star$ & $-\star \star *$ & \\
\hline Age 50-75 & & & $-\star \star$ & & & $-*$ \\
\hline Return migration to Finland & & $-* \star \star$ & $+* \star$ & & $-\star \star \star \star$ & $+* \star \star$ \\
\hline $\begin{array}{l}\text { Return migration to countries } \\
\text { other than Finland }\end{array}$ & $-* \star \star$ & $-\star \star \star *$ & $-\star \star \star *$ & $-* \star \star$ & $-\star \star \star *$ & $-\star \star \star *$ \\
\hline $\begin{array}{l}\text { Return migration of at least } 1 \\
\text { year }\end{array}$ & & & & & $-*$ & \\
\hline White collar job abroad & 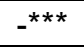 & $-\star \star \star *$ & $-*$ & $-* \star \star$ & $-\star \star \star *$ & $-\star \star$ \\
\hline
\end{tabular}

In addition to the baseline estimates presented above we undertook a number of additional estimations. In order to save space, Table 5 presents from these regressions only the signs and statistical significance of the coefficients of temporary migration in the upward occupational mobility equation. On most breakdowns the effect of temporary migration remained negative, with the exception of that to Finland, where it was positive for males. The negative effect also disappeared for return migration lasting for more than a year (though it could be related to the much smaller number of such episodes). These results do not rule out the possibility that there are positive impacts for some segments of workers. While we argued the observed association with downward 
mobility could be related to the kinds of jobs held in abroad (requiring lower skills and possibly not corresponding to the skill level of migrants), here negative association was revealed even among those with holding white-collar jobs in abroad. When using instead of the 1-digit rankings simply the mobility between white-collar and blue-collar jobs the return migration did not have any effects on the mobility. Negative effects were also revealed when using instrumental variables linear probability models instead of bivariate probit models with signs mostly the same as from bivariate probit models. Instead of just the modelling the dummy for upward mobility we also tried modelling the changes in the whole ranking of occupations using the ordered probit model (as did Carletto and Kilic 2011) and the results were qualitatively similar.

As one additional robustness check, we undertook to estimate the impact of return migration on the desired wages of return migrants. The descriptive evidence showed higher wage expectations among the returnees, throughout the wage distribution and for different groups of job-seekers. To have a closer look on it, we conducted a propensity score matching exercise (see e.g. Caliendo and Kopeinig 2008), by which returnees were matched with similar stayers based on a number of characteristics affecting the return migration in order to construct an appropriate control groups for the returnees. The matching involved estimating a probit model for the return migration where independent variables were gender, educational dummies, age and age squared, returns to occupations, family background (dummy for cohabitation and children), previous migration. Despite various specifications tried we did not find any evidence of positive effects of return migration (results available upon request). Finally, concerning the effect of temporary migration on self-employment in Estonia, Arro et al. (2013) found that although among early stage and nascent entrepreneurs there was a relatively higher share of people having lived abroad for at least 6 month in last 3 years (respectively 14.8 and $12.6 \%$ compared to $6.1 \%$ among non-entrepreneurs), after controlling for other various personal and socio-economic characteristics the variable for return (temporary) migration became insignificant.

\section{Qualitative evidence on the effect of temporary migration on labour market performance at home}

In order to complement the quantitative analysis we additionally conducted 75 structured interviews by phone to gather employers' opinions and attitudes about selected characteristics of the candidates. We interviewed randomly picked representatives of the organizations who had advertised vacancies in job portal CV Keskus in the period from March 2012 till June 2012. Among other questions we asked also about specifically how employers evaluate the presence of experience 
of working abroad of their job applicants. Approximately half (Table 6) of interviewees estimated the presence of experience of working abroad positively (positive and rather positive) and only 12\% of respondents perceived it as rather negative or negative aspect in candidate's resume. The proportion of negative attitude was highest among interviewees who recruited high-skilled bluecollar workers, 38\%. Comments show that this kind of evaluation could arise from two aspects: those who have worked abroad are eager to do it again and their reservation wage is too high. It was also said that specialists could gain from the experience of working abroad only in the case when it is connected with the field of activity where the candidate is applying. Command of foreign languages was also mentioned as positive aspect of working abroad. Presence of experience of working abroad is evaluated more highly in small organizations (64\% of respondents estimated either as positive or rather positive, among big firms 44\%). The biggest percentage of negative estimations was given by the interviewees of the secondary sector and the biggest share of positive valuations by the organizations from trade and service sector.

Table 6. Effect of candidate's previous experience of working abroad on personnel selection (on hiring)

\begin{tabular}{llllll}
\hline Occupation & Negative & $\begin{array}{l}\text { Rather } \\
\text { negative }\end{array}$ & $\begin{array}{l}\text { Neutral/no } \\
\text { effect }\end{array}$ & $\begin{array}{l}\text { Rather } \\
\text { positive }\end{array}$ & Positive \\
\hline All (n=75) & 1.3 & 10.7 & 40 & 32 & 16 \\
White-collar high skilled(n=16) & 0 & 0 & 37.5 & 37.5 & 25 \\
White-collar low skilled $(\mathrm{n}=30)$ & 0 & 0 & 43 & 47 & 10 \\
Blue-collar high skilled $(\mathrm{n}=21)$ & 5 & 33 & 33 & 10 & 19 \\
Blue-collar low skilled $(\mathrm{n}=8)$ & 0 & 12.5 & 50 & 25 & 12.5 \\
\hline
\end{tabular}

The above structured interviews were complemented by 29 semi-structured face-to-face interviews with employers' representatives. The interviews revealed that the benefits from working abroad can be quite varied. A 47 year old female from a large international production enterprise said: "International working experience is value, in case of young people even selling books. Age is important in how the employer evaluates international work experience. If one has not been successful in abroad then this nullifies the foreign experience. If you are an international enterprise, then the more international and wider are your work experience, the better”. Not all are successful in the home country labour market: "case by case, there are the ones who come back and get better jobs, and there are also the ones, who come back, and do not find job for a long period. That depends both on the individual and the situation of the economy" (32 years old male, energy sector). It is also revealed that there need not to be any technological gap between Estonia and its destination countries - foreign experience may matter "in terms of horizon and personal development, also how the work culture is there, how the work is organized. Not really in terms of 
professional qualification, as we do more complicate things” (51 years old male from small international service business). Also some negative effects were outlined - people returning from abroad might be more uncertain when applying, they are more uncertain about the adoption to local labour market; for people with foreign work experience it is also more easy to go back again due to the positive experience and the access to information (38 years old male from an international service business in Tallinn). Another employer (52 year old female from a small business) indicated that "I am very curious about the returnees as I do not know what their experience actually means".

We also conducted a few interviews with the job seekers. While in the literature it is a common claim that migrants return with newly acquired specific experience or skills, Katseli et al. (2006) claimed that the applicability of the specific skills acquired in foreign country may be limited due to technological gap between receiving and sending country. Our interviews indicated some cases and reasons when that might not be the case, for instance, one interviewed employee, a 52 years old doctor (female), who works both in Estonia and Finland, said that more than 10 years ago there was a lot to learn in Finland, but not any more, as the medicine system in Estonia is now at the same level as in Finland. Another 52 years man who worked in Finland in construction indicated that while in terms of work organization Estonia is even somewhat ahead, in Finland there is some advantage in terms of technical working methods. Also, many interviews revealed that the skills and knowledge acquired abroad are of use only when there is possible to apply these in the home country labour market (that is not necessarily always so).

\section{Conclusion}

Migration from Eastern to the Western Europe is an increasing phenomenon. Since much of it is of temporary nature, it is important to look into its effect on the sending countries labour markets via the relative performance of the returnees. In this paper we undertook an empirical estimation on the effect of return migration on upward occupational mobility in the ladder of occupations determined by their wages or required human capital using the unique dataset of the leading Estonian online job search portal. While the literature on home country labour market effects of return migration is not very large, especially the effect of return migration on occupational mobility has been looked into only in a small number of studies.

In general, when comparing the returnees' occupations in home country (Estonia) before and after the temporary migration we failed to find any evidence on the positive effect of return migration on the returnee's career mobility or upward movement in the occupational ladder, as was found in 
some earlier studies (Carletto and Kilic 2011, Cobo et al. 2010). In fact, there was negative effect on upward mobility in case of females. The similar result held also after various robustness checks, like different duration of migration, destination country (Finland as closest majour destination country versus the others), definitions of occupational ladder (constructed using required human capital versus returns in terms of earnings). These results may be related to both the functioning of the home country labour and the kind of the return migration, e.g. jobs held abroad and destination countries. Given the latter, while in case of the studies mentioned earlier the sending and recipient countries had usually rather large income and technological caps (respectively Albania versus Italy and Greece, and Latin-America versus USA), the gap is expectedly somewhat smaller in case of the outward migration from Estonia, thus as indicated also by the additional interviews with employers and job-seekers the knowledge transfer and skill accumulation effect might be of smaller importance in this context.

Also in line with earlier studies on East-West migrants returnees predominantly work in abroad in lower-skilled occupations potentially not corresponding to their qualifications which may explain the limited human capital accumulation. When looking additionally on the desired wages of the job seekers (which naturally could differ from reservation wages or actual wages) returnees had significantly higher wage claims, yet after controlling for differences in returnees and stayers in various personal and socio-economic characteristics no significant difference remained. That might be consistent with evidence on occupational mobility given that the latter could be one channel for getting higher wages. The negative effect of temporary migration in case of females may be related to their discrimination in the labour market, i.e. similar to their return to labour market after the maternity care. Another explanation on the lack of positive effects is the fast development of Estonian economy during the studied period, thus in case of returning the previous kinds of jobs might not be available anymore. Concerning remittances, while according to Hazans and Philips (2011) the remittances from migrants to Estonia were high enough to improve the financial situation of the households with migrants, the remittances in case of temporary migration might be of too limited size to significantly change the labour market behaviour of the returnees. Regarding the determinants of occupational mobility (returns to current and alternative occupations, transferability of skills, costs of mobility) there effects were mostly according to expectation; these result confirm the ones in Campos and Dabušinskas (2009) that after the early transition period the determinants of occupational mobility have been in accordance with the market mechanism. 
All in all, the results of the study in our opinion motivate a further study of the occupational choices of returnees for other CEE countries as the benefit for return migration should not be taken for granted. In terms of possible policy implications we need to keep in mind that most of the migration in this context takes place within the EU with right for free mobility of labour while the policy of Estonia towards migration from outside EU has been rather restrictive. The lack of evidence on positive effects of temporary migration in our paper need not rule out arguments for programmes attracting the returnees back home, like the Estonian initiative "Talendid koju” (in English: Talents back home) as the benefits of outward migration may still be there in case of some categories of individuals or through other mechanisms (like alleviating labour shortage in certain activities) thus it is important what are the characteristics of the returnees. A further study of the welfare effects of return migration and immigrants, including also their occupational choices, would be helpful in designing the appropriate policies. 


\section{References}

Anspal, S., L. Kraut and T. Rõõm (2010), Sooline palgalõhe Eestis: empiiriline analüüs. Uuringuraport. Eesti Rakendusuuringute Keskus CentAR, Poliitikauuringute Keskus PRAXIS, Sotsiaalministeerium.

Arro, T., Elenurm, T., Küttim, M., Liigus, E., Masso, J., Mets, T., Paes, K., Raudsaar, M., Rebane, K., Reino, A., Põder, K. (2013) Globaalne ettevõtlusmonitooring 2012 Eesti raport. Tallinn: Eesti Arengufond

Barrett A., O’Connell, P. J. (2001), ”Is There a Wage Premium for Returning Irish Migrants?”, Economic and Social Review, Vol. 32, Issue 1, pp. 1-21.

Borjas, G., Bratsberg, B. (1996), "Who leaves? The out-migration of the foreign-born”, Review of Economics Statistics, Vol. 78, Issue 1, pp. 165-76.

Brownell, P.B. (2010), “Wages differences between temporary and permanent immigrants”, International Migration Review, Volume 44, Number 3, pp. 593-614

Caliendo, M. Kopeinig, S. (2008), “Some Practical Guidance for the Implementation of Propensity Score Matching”, Journal of Economic Surveys, Vol. 22, pp. 31-72.

Campos, N. F., Dabušinskas, A. (2009), "So many rocket scientists, so few marketing clerks: Estimating the effects of economic reform on occupational mobility in Estonia”, European Journal of Political Economy, Vol. 25, pp. 261-275.

Carletto, C., Kilic T. (2011), "Moving Up the Ladder? The Impact of Migration Experience on Occupational Mobility in Albania”, Journal of Development Studies, Vol.47, No. 6, pp. 846-869

Co, C. Y., Gang, I. N., Yun, M. S. (2000), "Returns to returning”, Review of Development Economics, Vol. 9, Issue 2, pp. 150-165.

Cobo, S. D, Giorguli S. E., Alba, F. (2010), “Occupational Mobility among Returned Migrants in Latin America: A Comparative Analysis”, The ANNALS of the American Academy of Political and Social Science, 630, pp. 245-268

Commander, S., Nikolaychuk, O., Vikhrov, D. (2013), „Migration from Ukraine: Brawn or Brain?“, IZA Discussion Paper No. 7348.

De Coulon A., Piracha M. (2005), „Self-selection and the performance of return migrants: the source country perspective“, Journal of Population Economics, Vol. 18, Issue 4: 779-807

Dustmann, C. (2003), “Return migration, wage differentials and the optimal migration”, European Economic Review, Elsevier, vol. 47(2), pp. 353-369

Dustmann, C., Glitz, A., Frattini, T. (2008), „The labour market impact of immigration“, Oxford Review of Economic Policy, Vol. 24, Issue 3, 477-494. 
Fan, S., Stark, O. (2007), “The brain drain, 'educated unemployment', human capital formation, and economic betterment”, The Economics of Transition, Vol. 15, pp. 629-660,

Gibson, J., McKenzie, D. (2011), “The microeconomic determinants of emigration and return migration of the best and brightest: evidence from the Pacific”, Journal of Development Economics 95(1): 18-29.

Greene, W. (2000), „Econometric Analysis“, 4th ed., Prentice-Hall.

Hazans, M. (2008), ”Post-Enlargement Return Migrants' Earnings Premium: Evidence from Latvia” (September 17, 2008). Available at SSRN: http://ssrn.com/abstract=1269728 or doi:10.2139/ssrn.1269728

Hazans, M., Philips, K. (2011), „The Post-Enlargement Migration Experience in the Baltic Labor Markets“, in M. Kahanec and K. F. Zimmermann (eds.), EU Labor Markets After Post-Enlargement Migration, Berlin - Heidelberg: Springer, pp. 255-304.

Iara, A. (2006), „Skill Diffusion by Temporary Migration? Returns to Western European Working Experience in the EU Accession Countries“, WIIW Balkan Observatory Working Paper No. 069.

Ilahi, N. (1999), “Return Migration and Occupational Change”, Review of Development Economics, Vol. 3, Issue 2, pp. 170-186.

Kahanec, M., Shields, P. (2010), ”The Working Hours of Immigrants in Germany: Temporary versus Permanent”, IZA Discussion Paper No. 4735

Katseli, L. T., R. Lucas, Xenogiani, T. (2006), “Effects of migration on sending countries: what do we know?”, OECD Development Centre Working Paper No. 250.

King, R., Skeldon, R. (2010), “’Mind the Gap!’ Integrating Approaches to Internal and International Migration”, Journal of Ethnic and Migration Studies, Vol. 36, Issue 10, pp. 1619-1646.

Kupets, O. (2011), "Brain Gain or Brain Waste? The Performance of Return Labor Migrants in the Ukrainian Labor Market”, Economics Education and Research Consortium Working Paper No $11 / 06 \mathrm{E}$

Lowell, B. L., Findlay, A. M. (2002), ”Migration of highly skilled persons from developing countries: impact and policy responses - synthesis report”, ILO International Migration Paper No. 44.

Luthra, R. R. (2009), “Temporary Immigrants in a High-Skilled Labour Market: A Study of H1Bs”, Journal of Ethnic and Migration Studies, Vol. 35, Issue 2, pp. 227-250

Mattoo, A., Neagu, I. C., Ozden, C. (2008), „Brain waste? Educated immigrants in the US labour market“, Journal of Development Economics, Vol. 87, pp. 255-269.

Mõtsmees, P., Meriküll, J. (2012), “Palgalõhe meeste ja naiste palgaootustes”, University of Tartu, mimeo. 
Mesnard, A. (2004), “Temporary migration and self-employment”, Brussels Economic Review, Vol. 47, Issue 1, pp. 119-138.

Neal, D. (1999), “The complexity of job mobility among young men”, Journal of Labour Economics, Vol. 17, pp. 237-261.

Randveer, M., Rõõm, T. (2009), “The Structure of Migration in Estonia: Survey-Based Evidence”, Bank of Estonia Working Paper No. 1/2009.

Saarela, J., Finnas, F. (2009), "Return migrant status and employment in Finland”, International Journal of Manpower, Vol. 30, Issue 5, pp. 489-506.

Sabirianova, K., (2002) “The great human capital reallocation: a study of occupational mobility in transitional Russia”, Journal of Comparative Economics, Vol. 30, pp. 191-217.

Sicherman, N., Galor, O. (1990), “A theory of career mobility”, Journal of Political Economy, Vol. 98, pp. 169-192.

Sun, W. (2013), “The productivity of return migrants: the case of China’s "Sea Turtles””, IZA Journal of Migration, Vol. 2, Issue 5, pp. 1-19.

Woolridge, J. (2002), „Econometric Analysis of Cross Section and Panel Data“, The MIT Press. 